\title{
Pemupukan N, P, K, Dolomit, dan Pupuk Kandang pada Budidaya Kedelai di Lahan Kering Masam
}

\author{
Fertilization of N, P, K, Dolomite, and Manure on Soybean Cultivation in Acid Soil
}

Halimatus Syahdia Hasibuan ${ }^{1}$, Didy Sopandie ${ }^{2^{*}}$, Trikoesoemaningtyas ${ }^{2}$, dan Desta Wirnas ${ }^{2}$

${ }^{1}$ Program Studi Agronomi dan Hortikultura, Sekolah Pascasarjana, Institut Pertanian Bogor

${ }^{2}$ Departemen Agronomi dan Hortikultura, Fakultas Pertanian, Institut Pertanian Bogor

(Bogor Agricultural University), Jl. Meranti, Kampus IPB Darmaga, Bogor 16680, Indonesia

Diterima 4 September 2107/Disetujui 29 Juni 2018

\begin{abstract}
The imbalanced supply-demand of soybean is the main reason of soybean import in Indonesia. One of the efforts to increase of soybean production was expanding the planting area to acid soil with a low $\mathrm{pH}$, high content of Aluminum, and low nutrient availability, through giving ameliorant, such as liming organic materials, and mineral fertilization.This study was aimed to obtain the best combination of fertilizer and amelioran for soybean production in acid soil. The study was conducted in experimental station of Tenjo, Bogor from November 2015 to March 2016. The experiment used a randomized complete block design with two factors. The first factor was combinations of fertilizer and amelioran, i.e., P0 (without fertilization); $P 1\left\{25 \mathrm{~kg}\right.$ urea $+75 \mathrm{~kg} \mathrm{SP}-36+50 \mathrm{~kg} \mathrm{KCl}+$ dolomite $\left.1 / 4 \times \mathrm{Al}_{d d}(805 \mathrm{~kg}) \mathrm{ha} \mathrm{f}^{-1}\right\} ; P 2\{25 \mathrm{~kg}$ urea $+75 \mathrm{~kg} \mathrm{SP}-36+$ $50 \mathrm{~kg} \mathrm{KCl}+$ dolomite $1 / 4 \times \mathrm{Al}_{d d}(805 \mathrm{~kg})+1,250 \mathrm{~kg}$ of manure $\left.\mathrm{ha}^{-1}\right\} ; P 3\{50 \mathrm{~kg}$ urea $+75 \mathrm{~kg} \mathrm{SP}-36+50 \mathrm{~kg} \mathrm{KCl}+$ dolomite $1 / 4 \times \mathrm{Al}_{d d}(805 \mathrm{~kg})+2,500 \mathrm{~kg}$ of manure $\left.\mathrm{ha}^{-1}\right\} ; P 4\left\{75 \mathrm{~kg}\right.$ urea $+150 \mathrm{~kg} \mathrm{SP}-36+100 \mathrm{~kg} \mathrm{KCl}+$ dolomite $1 / 4 \times \mathrm{Al}_{d d}(805 \mathrm{~kg})+$ $2,500 \mathrm{~kg}$ of manure $\left.\mathrm{ha}^{-1}\right\} ; P 5\left\{75 \mathrm{~kg}\right.$ urea $+150 \mathrm{~kg} \mathrm{SP-36}+100 \mathrm{~kg} \mathrm{KCl}+$ dolomite $\left.1 / 2 \times \mathrm{Al}_{d d}(1,610 \mathrm{~kg}) \mathrm{ha} \mathrm{h}^{-1}\right\} ; P 6\{75 \mathrm{~kg}$ urea $+150 \mathrm{~kg} \mathrm{SP}-36+100 \mathrm{~kg} \mathrm{KCl}+$ dolomites $\left.1 \times \mathrm{Al}_{d d}(3,220 \mathrm{~kg}) \mathrm{ha}^{-1}\right\}$. The second factor was soybean varieties of Tanggamus and Anjasmoro. The results showed that application of $75 \mathrm{~kg}$ urea $+150 \mathrm{~kg} \mathrm{SP}-36+100 \mathrm{~kg} \mathrm{KCl}+$ dolomite $1 / 2 \times \mathrm{Al}_{d d}(1,610$ $\mathrm{kg}$ ) produced the highest productivity $\left(2.91\right.$ ton $\left.\mathrm{ha}^{-1}\right)$, but it was not different from reducing the dose of dolomite into $1 / 4 \times \mathrm{Al}_{d d}$ $(805 \mathrm{~kg})$ with the addition of $2,500 \mathrm{~kg}$ of manure.
\end{abstract}

Keywords: Al saturation, chemical properties of soil, nutrient uptake, produktivity, soil amelioran

\section{ABSTRAK}

Produksi kedelai yang tidak seimbang dengan kebutuhan masyarakat menyebabkan Indonesia mengambil kebijakan impor kedelai. Salah satu upaya meningkatkan produksi kedelai adalah dengan memperluas areal tanam ke lahan kering masam dengan kendala pH yang rendah, kandungan Alumunium tinggi, dan ketersediaan hara yang rendah. Upaya peningkatan produktivitas kedelai pada lahan kering masam dapat dilakukan dengan pemberian amelioran kapur, bahan organik, dan pupuk mineral. Penelitian ini bertujuan untuk memperoleh informasi tentang kombinasi pupuk dan amelioran terbaik untuk produksi kedelai di lahan kering masam. Penelitian dilaksanakan di lahan percobaan Tenjo Kabupaten Bogor dari bulan November 2015 hingga Maret 2016. Penelitian ini menggunakan rancangan kelompok lengkap teracak dengan dua faktor. Faktor pertama adalah kombinasi pupuk dan amelioran yaitu P0 (tanpa pemupukan); $P 1\{25 \mathrm{~kg}$ urea $+75 \mathrm{~kg}$ $S P-36+50 \mathrm{~kg} \mathrm{KCl}+$ dolomit $\left.1 / 4 x \mathrm{Al}_{d d}(805 \mathrm{~kg}) \mathrm{ha} \mathrm{C}^{-1}\right\} ; P 2\left\{25 \mathrm{~kg}\right.$ urea $+75 \mathrm{~kg} \mathrm{SP}-36+50 \mathrm{~kg} \mathrm{KCl}+$ dolomit 1/4 $x \mathrm{Al}_{d d}(805$ $\mathrm{kg})+1,250$ ton pupuk kandang $\left.\mathrm{ha}^{-1}\right) ; P 3\left\{50 \mathrm{~kg}\right.$ urea $+75 \mathrm{~kg} \mathrm{SP}-36+50 \mathrm{~kg} \mathrm{KCl}+$ dolomit $1 / 4 x^{1 / 2} \mathrm{Al}$ dd $(805 \mathrm{~kg})+2,500$ ton pupuk kandang ha $\left.{ }^{-1}\right\} ; P 4\left\{75 \mathrm{~kg}\right.$ urea $+150 \mathrm{~kg} \mathrm{SP}-36+100 \mathrm{~kg} \mathrm{KCl}+$ dolomit $^{1 / 4} \times \mathrm{Al} l_{d d}(805 \mathrm{~kg})+2,500$ ton pupuk kandang $\left.\mathrm{ha}^{-1}\right\} ; P 5\left\{75 \mathrm{~kg}\right.$ urea $+150 \mathrm{~kg} \mathrm{SP-36}+100 \mathrm{~kg} \mathrm{KCl}+$ dolomit $\left.^{1 / 2} \times \mathrm{Al}_{d d}(1,610 \mathrm{~kg}) \mathrm{ha}^{-1}\right\} ; P 6\{75 \mathrm{~kg}$ urea $+150 \mathrm{~kg} \mathrm{SP-36}$ $+100 \mathrm{~kg} \mathrm{KCl}+$ dolomit $1 \times \mathrm{Al}_{d d}(3,220 \mathrm{~kg}) \mathrm{ha^{-1 }}$. Faktor kedua adalah varietas kedelai yaitu Tanggamus dan Anjasmoro.

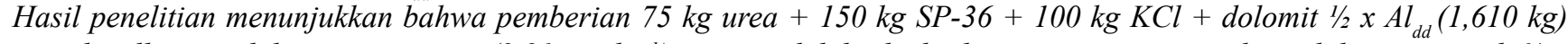
menghasilkan produktivitas tertinggi (2.91 ton $\mathrm{ha}^{-1}$ ), tetapi tidak berbeda dengan pengurangan dosis dolomit menjadi $1 / 4 \mathrm{x}$ $\mathrm{Al}_{d d}(805 \mathrm{~kg})$ dengan penambahan 2,500 kg pupuk kandang.

Kata kunci: amelioran tanah, kejenuhan Al, produktivitas, serapan hara, sifat kimia tanah

\footnotetext{
* Penulis untuk korespondensi. e-mail: didysopandie@gmail.com
} 


\section{PENDAHULUAN}

Peningkatan pertumbuhan jumlah penduduk dan berkembangnya industri pangan menyebabkan kebutuhan kedelai ikut meningkat. Kebutuhan kedelai di Indonesia mencapai 2.3 juta ton setiap tahun (Balitkabi, 2014). Produksi kedelai pada tahun 2015 mencapai 0.96 juta ton dengan produktivitas mencapai 1.57 ton $\mathrm{ha}^{-1}$ (BPS, 2015). Kondisi yang tidak seimbang antara kebutuhan dan ketersediaan menyebabkan negara Indonesia mengambil kebijakan mengimpor kedelai.

Salah satu upaya untuk meningkatkan produksi kedelai adalah dengan memperluas areal tanam ke lahanlahan sub-optimal, seperti lahan kering masam. Berdasarkan potensi luasan, lahan kering masam merupakan lahan suboptimal dengan luas areal 107.4 juta ha dan $48 \%$ dari total luas lahan kering masam terletak pada kemiringan lahan $<15 \%$ sehingga relatif sesuai untuk pertanian tanaman pangan (Balitbangtan, 2014). Kendala yang dihadapi dalam pemanfaatan lahan kering masam adalah $\mathrm{pH}$ yang rendah, tingginya kelarutan $\mathrm{Al}, \mathrm{Mn}$, dan Fe yang dapat meracuni tanaman, ketersediaan hara seperti $\mathrm{N}, \mathrm{P}, \mathrm{K}, \mathrm{Ca}, \mathrm{Mg}, \mathrm{Zn}$, $\mathrm{Mo}, \mathrm{Cu}$, dan $\mathrm{B}$ yang rendah, serta KTK dan bahan organik rendah (Taufiq et al., 2004).

Lahan kering masam memerlukan masukan teknologi untuk mengoptimalkan produktivitasnya. Beberapa hasil penelitian di lahan kering masam dengan tingkat keberadaan $\mathrm{Al}_{\mathrm{dd}}$ 1-2 me $100 \mathrm{~g}^{-1}$ dan kejenuhan $\mathrm{Al}$ rendah sampai tinggi menunjukkan bahwa pemberian pupuk berimbang dan penambahan amelioran kapur dapat meningkatkan produktivitas. Berdasarkan laporan hasil penelitian diketahui bahwa dosis pemupukan pada lahan kering masam berada pada kisaran 25-75 kg urea ha-1, 75-150 kg SP-36 ha-1, 50$100 \mathrm{~kg} \mathrm{KCl} \mathrm{ha}{ }^{-1}$, amelioran kapur antara $1 / 4-1 \mathrm{Al}_{\text {dd }} \mathrm{ha}^{-1}$, dan pupuk kandang antara 1-2.5 ton $\mathrm{ha}^{-1}$ (Taufiq et al., 2007; Sudaryono et al., 2011; Yunizar, 2014).

Tingkat kesuburan lahan kering masam setiap lokasi yang beragam menyebabkan perbedaan pemupukan untuk kedelai sehingga diperlukan suatu kalibrasi teknologi budidaya kedelai untuk lahan kering masam. Tipe lahan kering masam yang akan menjadi lingkungan target adalah yang tergolong ringan-sedang dengan $\mathrm{pH}$ sekitar 4.5-5, $\mathrm{Al}_{\text {dd }}$ 1-2 me $100 \mathrm{~g}^{-1}$, kejenuhan $\mathrm{Al}<25 \%$ (Kamprath, 1970; Sanchez, 1976). Kegiatan produksi kedelai akan menjadi tidak ekonomis pada lahan dengan cekaman tanah masam yang lebih berat. Tujuan dari penelitian ini adalah untuk memperoleh kombinasi pupuk dan amelioran terbaik untuk kedelai di lahan kering masam.

\section{BAHAN DAN METODE}

Penelitian dilaksanakan di lahan percobaan UPT Pengembangan Teknologi Lahan Kering Wilayah Tenjo Kabupaten Bogor. Penanaman dilakukan pada bulan Desember 2015 hingga Maret 2016. Curah hujan pada saat pelaksanaan penelitian adalah $334.2 \mathrm{~mm}$ (Desember), $236.4 \mathrm{~mm}$ (Januari), $196 \mathrm{~mm}$ (Februari), $175.6 \mathrm{~mm}$ (Maret).
Percobaan ini menggunakan Rancangan Kelompok Lengkap Teracak dengan dua faktor. Faktor pertama adalah kombinasi pupuk dan amelioran yaitu P0 (tanpa pemupukan); P1 \{25 $\mathrm{kg}$ urea $+75 \mathrm{~kg} \mathrm{SP}-36+50 \mathrm{~kg} \mathrm{KCl}+$ dolomit $1 / 4 \mathrm{x} \mathrm{Al}_{\mathrm{dd}}$ $\left.(805 \mathrm{~kg}) \mathrm{ha}^{-1}\right\}$; P2 $\{25 \mathrm{~kg}$ urea $+75 \mathrm{~kg} \mathrm{SP}-36+50 \mathrm{~kg} \mathrm{KCl}$ + dolomit $1 / 4 \mathrm{X} \mathrm{Al}_{\mathrm{dd}}(805 \mathrm{~kg})+1,250$ ton pupuk kandang) $\left.\mathrm{ha}^{-1}\right\}$; P3 $\{50 \mathrm{~kg}$ urea $+75 \mathrm{~kg} \mathrm{SP}-36+50 \mathrm{~kg} \mathrm{KCl}+$ dolomit $1 / 4 \times \mathrm{Al}_{\mathrm{dd}}(805 \mathrm{~kg})+2,500$ ton pupuk kandang ha $\left.{ }^{-1}\right\} ; \mathrm{P} 4$ $\{75 \mathrm{~kg}$ urea $+150 \mathrm{~kg} \mathrm{SP}-36+100 \mathrm{~kg} \mathrm{KCl}+$ dolomit $1 / 4$ $\mathrm{x} \mathrm{Al}_{\mathrm{dd}}(805 \mathrm{~kg})+2,500$ ton pupuk kandang ha-1 $\} ; \mathrm{P} 5\{75$ $\mathrm{kg}$ urea $+150 \mathrm{~kg} \mathrm{SP}-36+100 \mathrm{~kg} \mathrm{KCl}+$ dolomit $1 / 2 \mathrm{x} \mathrm{Al}_{\mathrm{dd}}$ $\left.(1,610 \mathrm{~kg}) \mathrm{ha}^{-1}\right\} ; \mathrm{P} 6\{75 \mathrm{~kg}$ urea $+150 \mathrm{~kg} \mathrm{SP}-36+100 \mathrm{~kg}$ $\mathrm{KCl}+$ dolomit $\left.1 \mathrm{x} \mathrm{Al}_{\mathrm{dd}}(3,220 \mathrm{~kg}) \mathrm{ha}^{-1}\right\}$. Kombinasi pupuk dan amelioran ditentukan dari hasil penelitian Taufiq et al. (2007), Sudaryono et al. (2011), dan Yunizar (2014). Faktor kedua adalah varietas kedelai yaitu Tanggamus (V1) dan Anjasmoro (V2).

Pengolahan lahan dilakukan tiga minggu sebelum tanam. Kemudian dibuat petakan ukuran $3 \mathrm{~m}$ x $4 \mathrm{~m}$ dengan tinggi $20 \mathrm{~cm}$. Diantara petakan dibuat saluran drainase dengan kedalaman $20 \mathrm{~cm}$, jarak antar petak dalam setiap ulangan $50 \mathrm{~cm}$ dan jarak antar ulangan $1 \mathrm{~m}$. Perlakuan dolomit dilakukan dua minggu sedangkan perlakuan pupuk kandang, urea, SP-36, $\mathrm{KCl}$ dilakukan satu minggu sebelum tanam dengan cara ditebar di atas tanah, lalu dicacah dengan cangkul hingga tercampur dengan tanah. Sebelum ditanam, benih kedelai dicampur dengan inokulum Rhizobium dengan dosis $5 \mathrm{~g} \mathrm{~kg}^{-1}$ benih dan insektisida carbosulfan $(5 \mathrm{~g}$ $\mathrm{kg}^{-1}$ benih kedelai). Jarak tanam yang digunakan adalah 40 $\mathrm{cm}$ x $10 \mathrm{~cm}$, dengan dua benih per lubang. Pemeliharaan yang dilakukan adalah penyulaman, penyiangan, dan pengendalian serangan hama dan penyakit dengan bahan aktif deltametrin setiap minggu dari umur tanaman 2 sampai 10 minggu setelah tanam (MST). Penyulaman dilakukan pada 7-10 hari setelah tanam. Penyiangan dilakukan pada umur 3 dan 7 MST. Panen dilakukan ketika 90\% daun sudah rontok, polong berwarna kuning atau coklat, dan mengering $(>90$ hari setelah tanam (HST).

Analisis kimia tanah ( $\mathrm{pH}, \mathrm{N}, \mathrm{P}, \mathrm{K}, \mathrm{Ca}, \mathrm{Mg}, \mathrm{Na}, \mathrm{KTK}$, dan $\mathrm{Al}$ ) dilakukan sebelum perlakuan dan setelah panen. Analisis kandungan N, P, dan K jaringan tanaman dilakukan pada umur 6 MST dengan mengambil daun ketiga atau keempat dari 30-40 tanaman yang dipilih secara acak. Perhitungan serapan hara menggunakan rumus: Serapan hara (mg per tanaman) = kandungan hara daun $(\%) \mathrm{x}$ bobot kering tanaman (Adeli et al., 2005). Komponen pertumbuhan vegetatif diamati pada umur $6 \mathrm{MST}$, yaitu luas daun diukur dengan aplikasi blackspot 1.0 (Varma dan Osuri, 2013) dengan mengambil satu tanaman contoh) dan jumlah cabang (10 tanaman contoh). Komponen hasil diamati pada saat panen, yaitu jumlah polong isi dan bobot 100 biji (10 tanaman contoh), dan produktivitas (ubinan $2 \times 2 \mathrm{~m}$ ).

Data yang diperoleh dianalisis menggunakan uji F pada taraf 5\%. Hasil yang berbeda nyata diuji lanjut dengan Duncan Multiple Range Test (DMRT). Analisis data menggunakan aplikasi SAS 9.2. 


\section{HASIL DAN PEMBAHASAN}

\section{Sifat Kimia Tanah}

Hasil analisis tanah sebelum perlakuan menunjukkan bahwa tanah pada lokasi penelitian merupakan lahan kering dengan kemasaman sedang, $\mathrm{pH} 4.9, \mathrm{Al}_{\mathrm{dd}} 1.75$ me $100 \mathrm{~g}^{-1}$, dan kejenuhan Al 10.68\% (Tabel 1). Secara umum, semua kombinasi pupuk dan amelioran meningkatkan nilai $\mathrm{pH}$, kandungan P-tersedia, $\mathrm{Ca}_{\mathrm{dd}}, \mathrm{Mg}_{\mathrm{dd}}, \mathrm{K}_{\mathrm{dd}}$, dan kejenuhan basa, serta menurunkan $\mathrm{Al}_{\mathrm{dd}}$ dan kejenuhan $\mathrm{Al}$ dibandingkan dengan tanpa perlakuan (Tabel 1). Pemberian $75 \mathrm{~kg}$ urea + $150 \mathrm{~kg} \mathrm{SP}-36+100 \mathrm{~kg} \mathrm{KCl}+$ dolomit $1 / 2-1 \times \mathrm{Al}_{\text {dd }}(1,610-$ $3,220 \mathrm{~kg}$ ) ha-1 (P5 dan P6) adalah yang terbaik dalam meningkatkan $\mathrm{pH}>5.5$, menurunkan $\mathrm{Al}_{\mathrm{dd}}$ dan kejenuhan $\mathrm{Al}$ menjadi tidak terukur. Pemberian $25 \mathrm{~kg}$ urea $+75 \mathrm{~kg}$ SP-36 + $50 \mathrm{~kg} \mathrm{KCl}+$ dolomit $1 / 4 \mathrm{x} \mathrm{Al}_{\mathrm{dd}}(805 \mathrm{~kg}) \mathrm{ha}^{-1}$ (P1) sudah dapat meningkatkan $\mathrm{pH}$ walaupun masih tergolong masam, tetapi menurunkan $\mathrm{Al}_{\mathrm{dd}}$ dan kejenuhan $\mathrm{Al}$ hingga enam kali lipat sehingga kandungan P-tersedia juga meningkat. Peningkatan dosis pupuk SP-36 hingga dua kali lipat (P4, P5, P6) tidak meningkatkan kandungan P-tersedia. Hal ini menunjukkan bahwa peningkatan kandungan P-tersedia dipengaruhi oleh pemberian dolomit.

Penambahan pupuk kandang dan pupuk anorganik (P2-P4) tidak membuat sifat kimia tanah menjadi lebih baik dibandingkan dengan pemberian pupuk anorganik dan dolomit (P1). Menurut Melati et al. (2008) pupuk kandang memerlukan proses dekomposisi yang lama sehingga ketersediaan hara menjadi lambat. Hal ini menunjukkan bahwa pemberian dolomit saja sudah dapat meningkakan $\mathrm{pH}$ dan menurunkan $\mathrm{Al}_{\mathrm{dd}}$ di tanah masam sehingga meningkatkan kation-kation basa tanah walaupun tanpa pupuk anoganik dan pupuk kandang. Hal yang sama juga ditemukan oleh Agustina et al. (2010), Verde et al. (2013), dan Muindi et al. (2015). Kapur yang larut dalam tanah akan melepas ion $\mathrm{Ca}^{2+}$ dan $\mathrm{Mg}^{2+}$ dan menggantikan ion $\mathrm{H}^{+}$ dan $\mathrm{Al}^{3+}$ (Kisinyo, 2016).
Kandungan $\mathrm{Ca}_{\mathrm{dd}}, \mathrm{Mg}_{\mathrm{dd}}$, dan $\mathrm{K}_{\mathrm{dd}}$ menurun pada perlakuan tanpa kombinasi pupuk dan amelioran tanah dibandingkan dengan sebelum diberi perlakuan. Hal ini disebabkan kandungan $\mathrm{Ca}, \mathrm{Mg}$, dan $\mathrm{K}$ yang ada di tanah diserap oleh tanaman untuk meningkatkan pertumbuhan. Kandungan $\mathrm{Ca}$ dan $\mathrm{Mg}$ di tanah dipengaruhi oleh pemberian dolomit dan pupuk kandang (Taufiq et al., 2007).

\section{Serapan Hara Total}

Interaksi pemberian kombinasi pupuk dan amelioran dengan varietas berpengaruh nyata terhadap serapan hara total $\mathrm{N}$, $\mathrm{P}$, dan $\mathrm{K}$, kecuali serapan hara total $\mathrm{K}$ pada Tanggamus (Tabel 2). Tanggamus memiliki serapan total hara $\mathrm{N}$ dan $\mathrm{P}$ tertinggi pada pemberian $75 \mathrm{~kg}$ urea +150 $\mathrm{kg} \mathrm{SP}-36+100 \mathrm{~kg} \mathrm{KCl}+$ dolomit $1 \mathrm{x} \mathrm{Al}_{\mathrm{dd}}(3,220 \mathrm{~kg}) \mathrm{ha}^{-1}$ (P6), tetapi tidak berbeda nyata dengan mengurangi dosis dolomit menjadi $1 / 2 \times \mathrm{Al}_{\mathrm{dd}}(1,610 \mathrm{~kg})$ atau $1 / 4 \times \mathrm{Al}_{\mathrm{dd}}$ (805 kg) dengan penambahan $2,500 \mathrm{~kg}$ pupuk kandang (P5-P3). Anjasmoro memiliki serapan hara total N, P, dan $\mathrm{K}$ tertinggi pada pemberian $25 \mathrm{~kg}$ urea $+75 \mathrm{~kg} \mathrm{SP}-36+$ $50 \mathrm{~kg} \mathrm{KCl}+$ dolomit $1 / 4 \mathrm{x} \mathrm{Al}_{\mathrm{dd}}(805 \mathrm{~kg})+1,250 \mathrm{~kg}$ pupuk kandang ha-1 $(\mathrm{P} 2)$, tetapi tidak berbeda nyata dengan tanpa pupuk kandang (P1) atau penambahan dosis kombinasi pupuk dan amelioran hinggga dua kali lipat (P4 dan P5). Hal ini menunjukkan bahwa Tanggamus lebih responsif terhadap pemberian dosis kombinasi pupuk dan amelioran yang tinggi dibanding Anjasmoro, namun nilai serapan hara total tidak berbeda nyata. Hal ini disebabkan Anjasmoro memiliki total biomass lebih banyak dibanding Tanggamus. Darwesh et al. (2013) menyatakan bahwa penyerapan hara dipengaruhi oleh total biomassa yang dihasilkan. Menurut Bachtiar et al. (2015) Tanggamus merupakan varietas yang cukup adaptif dan toleran di lahan kering. Varietas yang toleran memiliki nilai efisiensi penggunaan hara yang lebih tinggi sehingga akan mengarahkan pembagian fotosintat yang lebih ke daerah akar untuk meningkatkan kemampuan akar menyerap hara mineral pada keadaan tercekam hara (Agustina et al., 2010).

Tabel 1. Sifat kimia tanah sebelum dan setelah pemberian kombinasi pupuk dan amelioran

\begin{tabular}{|c|c|c|c|c|c|c|c|c|}
\hline Variabel & $\mathrm{P}$ & $\mathrm{P} 0$ & $\mathrm{P} 1$ & $\mathrm{P} 2$ & P3 & $\mathrm{P} 4$ & $\mathrm{P} 5$ & P6 \\
\hline $\mathrm{pH}\left(\mathrm{H}_{2} \mathrm{O}\right)$ & 4.90 & 4.60 & 4.99 & 4.83 & 4.87 & 4.90 & 5.56 & 5.88 \\
\hline N-total (\%) & 0.11 & 0.20 & 0.16 & 0.17 & 0.16 & 0.11 & 0.17 & 0.16 \\
\hline P-tersedia (pp) & 4.83 & 3.90 & 10.50 & 5.50 & 7.30 & 5.10 & 9.60 & 11.10 \\
\hline $\mathrm{Ca}_{\mathrm{dd}}\left(\right.$ me $\left.100 \mathrm{~g}^{-1}\right)$ & 7.11 & 1.62 & 9.95 & 8.25 & 9.09 & 8.11 & 11.05 & 12.11 \\
\hline $\operatorname{Mg}_{\mathrm{dd}}\left(\right.$ me $\left.100 \mathrm{~g}^{-1}\right)$ & 3.91 & 0.50 & 2.37 & 2.12 & 2.30 & 2.30 & 2.28 & 2.39 \\
\hline $\mathrm{K}_{\mathrm{dd}}\left(\mathrm{me} 100 \mathrm{~g}^{-1}\right)$ & 0.20 & 0.06 & 0.17 & 0.15 & 0.21 & 0.15 & 0.13 & 0.12 \\
\hline Kejenuhan basa (\%) & 70.33 & 13.54 & 72.86 & 64.54 & 72.78 & 75.25 & 95.93 & 100.00 \\
\hline $\mathrm{Al}_{\mathrm{dd}}\left(\mathrm{me} 100 \mathrm{~g}^{-1}\right)$ & 1.75 & 1.97 & 0.31 & 0.62 & 0.62 & 0.52 & 0.00 & 0.00 \\
\hline Kejenuhan Al (\%) & 10.68 & 11.30 & 1.78 & 3.72 & 3.82 & 3.65 & 0.00 & 0.00 \\
\hline
\end{tabular}

Keterangan: Urea : SP-36 : KCl : dolomit : pupuk kandang $\left(\mathrm{kg} \mathrm{ha}^{-1}\right) ; \mathrm{P}=$ sebelum perlakuan; $\mathrm{P} 0=0: 0: 0: 0: 0 ; \mathrm{P} 1=25: 75: 50: 1 / 4 \mathrm{X}$ $\mathrm{Al}_{\mathrm{dd}}(805): 0 ; \mathrm{P} 2=25: 75: 50: 1 / 4 \mathrm{X} \mathrm{Al}_{\mathrm{dd}}(805): 1250 ; \mathrm{P} 3=50: 75: 50: 1 / 4 \times \mathrm{Al}_{\mathrm{dd}}(805): 2500 ; \mathrm{P} 4=75: 150: 100: 1 / 4 \times \mathrm{Al}_{\mathrm{dd}}$ (805) : 2500; P5 = $75: 150: 100: 1 / 2 \times \mathrm{Al}_{\mathrm{dd}}(1610) ; \mathrm{P} 6=75: 150: 100: 1 \times \mathrm{Al}_{\mathrm{dd}}(3220)$ 
Tabel 2. Interaksi kombinasi pupuk dan amelioran dengan varietas terhadap serapan total hara daun

\begin{tabular}{llccccc}
\hline Kombinasi & \multicolumn{5}{c}{ Serapan total hara (mg per tanaman) } \\
\cline { 2 - 7 } $\begin{array}{l}\text { pupuk dan } \\
\text { amelioran }\end{array}$ & \multicolumn{1}{c}{$\mathrm{N}$} & $\mathrm{P}$ & $\mathrm{K}$ & Anjasmoro \\
\cline { 2 - 7 } & Tanggamus & Anjasmoro & Tanggamus & Anjasmoro & Tanggamus & $49.04 \mathrm{c}$ \\
\hline P0 & $134.45 \mathrm{~d}$ & $144.25 \mathrm{~d}$ & $7.14 \mathrm{~d}$ & $12.11 \mathrm{bcd}$ & $57.68 \mathrm{abc}$ & $76.15 \mathrm{abc}$ \\
P1 & $159.25 \mathrm{~cd}$ & $219.16 \mathrm{abcd}$ & $10.19 \mathrm{~cd}$ & $17.95 \mathrm{abcd}$ & $50.88 \mathrm{bc}$ & $140.07 \mathrm{a}$ \\
P2 & $133.44 \mathrm{~d}$ & $388.51 \mathrm{a}$ & $7.46 \mathrm{~d}$ & $30.43 \mathrm{a}$ & $49.17 \mathrm{c}$ & $56.39 \mathrm{abc}$ \\
P3 & $245.16 \mathrm{abcd}$ & $127.52 \mathrm{~d}$ & $16.89 \mathrm{abcd}$ & $9.39 \mathrm{~cd}$ & $98.15 \mathrm{abc}$ & $120.27 \mathrm{ab}$ \\
P4 & $165.99 \mathrm{bcd}$ & $277.14 \mathrm{abcd}$ & $12.60 \mathrm{abcd}$ & $21.23 \mathrm{abc}$ & $55.41 \mathrm{abc}$ & $120.83 \mathrm{ab}$ \\
P5 & $298.54 \mathrm{abd}$ & $338.47 \mathrm{abc}$ & $20.94 \mathrm{abc}$ & $26.15 \mathrm{ab}$ & $87.08 \mathrm{abc}$ & $50.57 \mathrm{bc}$ \\
P6 & $362.45 \mathrm{a}$ & $1,158.94 \mathrm{~cd}$ & $27.25 \mathrm{a}$ & $11.65 \mathrm{bcd}$ & $107.31 \mathrm{abc}$ & \\
\hline
\end{tabular}

Keterangan: Angka-angka sekolom dan sebaris yang diikuti oleh huruf yang sama pada masing masing peubah menunjukkan nilai tidak berbeda nyata pada uji DMRT taraf 5\%. Urea : SP-36: KCl : dolomit : pupuk kandang $\left(\mathrm{kg} \mathrm{ha}^{-1}\right) ; \mathrm{P} 0=0: 0: 0: 0: 0 ; \mathrm{P} 1=25$ $: 75: 50: 1 / 4 \mathrm{x} \mathrm{Al}_{\mathrm{dd}}(805): 0 ; \mathrm{P} 2=25: 75: 50: 1 / 4 \mathrm{x} \mathrm{Al}_{\mathrm{dd}}(805): 1250 ; \mathrm{P} 3=50: 75: 50: 1 / 4 \mathrm{x} \mathrm{Al}_{\mathrm{dd}}(805): 2500 ; \mathrm{P} 4=75: 150:$ $100: 1 / 4 \mathrm{x} \mathrm{Al}_{\mathrm{dd}}(805): 2500 ; \mathrm{P} 5=75: 150: 100: 1 / 2 \times \mathrm{Al}_{\mathrm{dd}}(1610) ; \mathrm{P} 6=75: 150: 100: 1 \times \mathrm{Al}_{\mathrm{dd}}(3220)$

\section{Pertumbuhan Vegetatif}

Interaksi pemberian kombinasi pupuk dan amelioran dengan varietas berpengaruh nyata terhadap luas daun dan jumlah cabang (Tabel 3). Tanggamus memiliki luas daun dan jumlah cabang tertinggi pada pemberian $75 \mathrm{~kg}$ urea $+150 \mathrm{~kg} \mathrm{SP}-36+100 \mathrm{~kg} \mathrm{KCl}+$ dolomit $1 \times \mathrm{Al}_{\mathrm{dd}}(3,220$ $\mathrm{kg}) \mathrm{ha}^{-1}(\mathrm{P} 6)$, tetapi tidak berbeda nyata mengurangi dosis dolomit menjadi $1 / 2 \times \mathrm{Al}_{\mathrm{dd}}(1,610 \mathrm{~kg})$ atau $1 / 4 \times \mathrm{Xl}_{\mathrm{dd}}(805 \mathrm{~kg})$ dengan penambahan 2,500 kg pupuk kandang (P5-P4). Anjasmoro memiliki luas daun dan jumlah cabang tertinggi pada pemberian $75 \mathrm{~kg}$ urea $+150 \mathrm{~kg} \mathrm{SP}-36+100 \mathrm{~kg} \mathrm{KCl}$ + dolomit $1 / 4 \mathrm{X} \mathrm{Al}_{\mathrm{dd}}(805 \mathrm{~kg})+2,500 \mathrm{~kg}$ pupuk kandang ha ${ }^{-1}$ (P4), tetapi tidak berbeda nyata dengan mengurangi dosis pupuk anorganik $50 \mathrm{~kg}$ urea $+75 \mathrm{~kg} \mathrm{SP}-36+50 \mathrm{~kg} \mathrm{KCl}$ (P3) atau meningkatkan dosis dolomit menjadi $1 / 2 \mathrm{X} \mathrm{Al}_{\mathrm{dd}}$ $(1,610 \mathrm{~kg})$ (P5). Peningkatan dosis dolomit menjadi $1 \mathrm{x}$ $\mathrm{Al}_{\text {dd }}(3,220 \mathrm{~kg})$ menurunkan luas daun pada Anjasmoro. Hal ini menunjukkan bahwa kedua varietas memiliki respon yang berbeda terhadap perlakuan kombinasi pupuk dan amelioran. Varietas Tanggamus lebih responsif terhadap pemberian dosis dolomit yang tinggi, sedangkan Anjasmoro lebih responsif terhadap dosis dolomit yang lebih rendah tetapi dengan pemberian pupuk kandang. Hal ini disebabkan karena varietas yang kurang toleran seperti varietas Anjasmoro memiliki akar yang pendek sehingga membutuhkan pemberian pupuk kandang. Menurut Hanum et al. (2009) Anjasmoro memiliki akar yang pendek sehingga kurang efisien dalam penyerapan hara. Pemberian bahan organik dapat memperbaiki sifat fisik tanah sehingga meningkatkan pertumbuhan akar dan penyerapan hara (Triadiati et al., 2013). Pupuk kandang meningkatkan serapan hara $\mathrm{N}$ dan $\mathrm{P}$ yang menyebabkan jumlah daun dan cabang meningkat sehingga bobot tanaman juga meningkat (Suge et al., 2011).

\section{Komponen Hasil}

Interaksi pemberian kombinasi pupuk dan amelioran dengan varietas berpengaruh terhadap jumlah polong isi

Tabel 3. Interaksi kombinasi pupuk dan amelioran dengan varietas terhadap luas daun dan jumlah cabang

\begin{tabular}{lcccc}
\hline \multirow{2}{*}{$\begin{array}{l}\text { Kombinasi pupuk } \\
\text { dan amelioran }\end{array}$} & Tanggamus & Anjasmoro & Tanggamus & Anjasmoro \\
\cline { 2 - 5 } P0 & $423.6 \mathrm{c}$ & $437.2 \mathrm{c}$ & $0.07 \mathrm{e}$ & $0.82 \mathrm{~d}$ \\
P1 & $486.6 \mathrm{c}$ & $530.9 \mathrm{bc}$ & $0.87 \mathrm{~d}$ & $1.70 \mathrm{bcd}$ \\
P2 & $457.2 \mathrm{c}$ & $642.5 \mathrm{abc}$ & $0.97 \mathrm{~cd}$ & $1.17 \mathrm{~cd}$ \\
P3 & $472.7 \mathrm{c}$ & $866.1 \mathrm{ab}$ & $1.39 \mathrm{bcd}$ & $2.10 \mathrm{abc}$ \\
P4 & $806.6 \mathrm{abc}$ & $920.1 \mathrm{a}$ & $1.91 \mathrm{abcd}$ & $2.12 \mathrm{abc}$ \\
P5 & $789.9 \mathrm{abc}$ & $881.8 \mathrm{ab}$ & $2.60 \mathrm{ab}$ & $2.13 \mathrm{abc}$ \\
P6 & $948.2 \mathrm{a}$ & $512.4 \mathrm{bc}$ & $3.07 \mathrm{a}$ & $1.47 \mathrm{bcd}$ \\
\hline
\end{tabular}

Keterangan: Angka-angka sekolom dan sebaris yang diikuti oleh huruf yang sama pada masing masing peubah menunjukkan nilai tidak berbeda nyata pada uji DMRT taraf 5\%. Urea : SP-36: KCl : dolomit : pupuk kandang $\left(\mathrm{kg} \mathrm{ha}^{-1}\right) ; \mathrm{P} 0=0: 0: 0: 0: 0 ; \mathrm{P} 1=25$ $: 75: 50: 1 / 4 \mathrm{X} \mathrm{Al}_{\mathrm{dd}}(805): 0 ; \mathrm{P} 2=25: 75: 50: 1 / 4 \mathrm{X} \mathrm{Al}_{\mathrm{dd}}(805): 1250 ; \mathrm{P} 3=50: 75: 50: 1 / 4 \mathrm{X} \mathrm{Al}_{\mathrm{dd}}(805): 2500 ; \mathrm{P} 4=75: 150$ $: 100: 1 / 4 \mathrm{X} \mathrm{Al}_{\mathrm{dd}}(805): 2500 ; \mathrm{P} 5=75: 150: 100: 1 / 2 \mathrm{x} \mathrm{Al}_{\mathrm{dd}}(1610) ; \mathrm{P} 6=75: 150: 100: 1 \times \mathrm{Al}_{\mathrm{dd}}^{\mathrm{dd}}(3220)$ 
dan bobot 100 biji, kecuali bobot 100 biji pada Tanggamus (Tabel 4). Tanggamus memiliki jumlah polong isi tertinggi pada pemberian $75 \mathrm{~kg}$ urea $+150 \mathrm{~kg} \mathrm{SP}-36+100 \mathrm{~kg} \mathrm{KCl}$ + dolomit $1 \times \mathrm{Al}_{\mathrm{dd}}(3220 \mathrm{~kg}) \mathrm{ha}^{-1}(\mathrm{P} 6)$, lalu pemberian $75 \mathrm{~kg}$ urea $+150 \mathrm{~kg} \mathrm{SP}-36+100 \mathrm{~kg} \mathrm{KCl}+$ dolomit $1 / 2 \mathrm{x} \mathrm{Al}_{\mathrm{dd}}(1610)$ ha $^{-1}$ (P5), tetapi tidak berbeda nyata dengan mengurangi dosis dolomit dan pupuk anorganik dengan penambahan 2,500 kg pupuk kandang (P4 dan P3). Bandyopadhyay et al. (2010) juga menemukan hasil yang sama bahwa hasil biji kedelai meningkat dengan pemberian pupuk kandang.
Jumlah polong isi dan bobot 100 biji pada Anjasmoro meningkat pada pemberian kombinasi pupuk dan amelioran dibandingkan dengan tanpa perlakuan. Peningkatan jumlah polong isi dan bobot 100 biji dipengaruhi oleh peningkatan kandungan hara P. Menurut Thoyyibah et al. (2014) kandungan $\mathrm{P}$ yang cukup pada tanaman akan menghasilkan fotosintat yang lebih banyak sehingga dapat ditranslokasikan ke dalam biji dengan optimal. Selain itu, jumlah polong isi juga dipengaruhi oleh kandungan $\mathrm{K}$ (Noya et al., 2014). Tanggamus memiliki jumlah polong isi yang lebih

Tabel 4. Interaksi kombinasi pupuk dan amelioran dengan varietas terhadap jumlah polong isi dan bobot 100 biji

\begin{tabular}{lcccc}
\hline \multirow{2}{*}{$\begin{array}{l}\text { Kombinasi pupuk } \\
\text { dan amelioran }\end{array}$} & \multicolumn{2}{c}{ Jumlah polong isi } & \multicolumn{2}{c}{ Bobot 100 biji (g) } \\
\cline { 2 - 5 } & Tanggamus & Anjasmoro & Tanggamus & Anjasmoro \\
\hline P0 & $13.21 \mathrm{e}$ & $15.34 \mathrm{e}$ & $9.00 \mathrm{c}$ & $14.22 \mathrm{~b}$ \\
P1 & $28.40 \mathrm{cde}$ & $32.37 \mathrm{~cd}$ & $9.41 \mathrm{c}$ & $16.27 \mathrm{a}$ \\
P2 & $29.90 \mathrm{cde}$ & $27.23 \mathrm{cde}$ & $9.72 \mathrm{c}$ & $16.36 \mathrm{a}$ \\
P3 & $38.33 \mathrm{bc}$ & $20.56 \mathrm{de}$ & $9.09 \mathrm{c}$ & $16.39 \mathrm{a}$ \\
P4 & $43.04 \mathrm{bc}$ & $33.88 \mathrm{~cd}$ & $9.50 \mathrm{c}$ & $16.56 \mathrm{a}$ \\
P5 & $51.03 \mathrm{~b}$ & $28.70 \mathrm{cde}$ & $9.87 \mathrm{c}$ & $16.69 \mathrm{a}$ \\
P6 & $72.75 \mathrm{a}$ & $33.00 \mathrm{~cd}$ & $9.85 \mathrm{c}$ & $16.86 \mathrm{a}$ \\
\hline
\end{tabular}

Keterangan: Angka-angka sekolom dan sebaris yang diikuti oleh huruf yang sama pada masing masing peubah menunjukkan nilai tidak berbeda nyata pada uji DMRT taraf $5 \%$. Urea : SP-36: KCl : dolomit : pupuk kandang $\left(\mathrm{kg} \mathrm{ha}^{-1}\right) ; \mathrm{P} 0=0: 0: 0: 0: 0 ; \mathrm{P} 1=25$ $: 75: 50: 1 / 4 \mathrm{X} \mathrm{Al}_{\mathrm{dd}}(805): 0 ; \mathrm{P} 2=25: 75: 50: 1 / 4 \mathrm{X} \mathrm{Al}_{\mathrm{dd}}(805): 1250 ; \mathrm{P} 3=50: 75: 50: 1 / 4 \mathrm{X} \mathrm{Al}_{\mathrm{dd}}(805): 2500 ; \mathrm{P} 4=75: 150:$ $100: 1 / 4 \mathrm{x} \mathrm{Al}_{\mathrm{dd}}(805): 2500 ; \mathrm{P} 5=75: 150: 100: 1 \frac{1}{2} \times \mathrm{Al}_{\mathrm{dd}}(1610) ; \mathrm{P} 6=75: 150: 100: 1 \times \mathrm{Al}_{\mathrm{dd}}^{\mathrm{dd}}(3220)$

tinggi dibanding Anjasmoro, walaupun serapan total hara kedua varietas tidak berbeda. Hal ini menunjukkan bahwa peningkatan serapan total hara tidak selalu meningkatkan produktivitas. Manshuri (2010) juga menemukan hasil yang sama.

Pemberian $75 \mathrm{~kg}$ urea $+150 \mathrm{~kg}$ SP-36 $+100 \mathrm{~kg}$ $\mathrm{KCl}+$ dolomit $1 \mathrm{x} \mathrm{Al}_{\mathrm{dd}}(3,220 \mathrm{~kg}) \mathrm{ha}^{-1}(\mathrm{P} 6)$ menghasilkan poduktivitas tertinggi, tetapi tidak berbeda nyata dengan mengurangi dosis dolomit menjadi $1 / 2 \times \mathrm{Al}_{\mathrm{dd}}(1610 \mathrm{~kg})$ (P5) atau $1 / 4 \mathrm{X} \mathrm{Al}_{\mathrm{dd}}(805 \mathrm{~kg})$ dengan penambahan $2,500 \mathrm{~kg}$ pupuk kandang (P4) (Tabel 5). Hal ini menunjukkan bahwa jika ketersediaan dolomit terbatas, maka dapat digantikan dengan pupuk kandang. Penelitian Taufiq et al. (2007) juga menemukan hasilyang sama pada tanah kering masam dengan pH 4.7-4.9 dan kejenuhan Al 15-19\%, namun produktivitas lebih rendah. Perbedaan produktivitas disebabkan kejenuhan Al yang berbeda. Kejenuhan Al tanah merupakan alat ukur toksisitas Al (Noya et al., 2014). Aluminium di tanah masam dapat mempengaruhi jumlah kation bervalensi dua yang diserap oleh akar tanaman khususnya $\mathrm{Ca}$ (Agustina et al., 2010). Hal ini menunjukkan bahwa semakin tinggi kejenuhan $\mathrm{Al}$ di tanah maka pemberian dolomit juga semakin tinggi agar diperoleh produktivitas yang optimal. Pada penelitian ini diperoleh bahwa produktivitas Tanggamus dan Anjasmoro tidak berbeda di lahan kering masam. Tabel 4 menunjukkan jumlah polong isi Tanggamus dua kali lebih
Tabel 5. Produktivitas kedelai pada perlakuan kombinasi pupuk dan amelioran dan perlakuan varietas

\begin{tabular}{lc}
\hline $\begin{array}{l}\text { Kombinasi pupuk dan } \\
\text { amelioran }\end{array}$ & Produktivitas $\left(\right.$ ton $\left.\mathrm{ha}^{-1}\right)$ \\
\hline P0 & $1.18 \mathrm{c}$ \\
P1 & $2.15 \mathrm{~b}$ \\
P2 & $2.16 \mathrm{~b}$ \\
P3 & $2.17 \mathrm{~b}$ \\
P4 & $2.91 \mathrm{ab}$ \\
P5 & $2.96 \mathrm{ab}$ \\
P6 & $3.36 \mathrm{a}$ \\
\hline Varietas & \\
\hline Tanggamus & $2.34 \mathrm{a}$ \\
Anjasmoro & $2.48 \mathrm{a}$ \\
\hline
\end{tabular}

Keterangan: Angka-angka yang diikuti oleh huruf yang sama menunjukkan nilai tidak berbeda nyata pada uji DMRT taraf 5\%. Urea : SP-36 : $\mathrm{KCl}:$ dolomit : pupuk kandang $\left(\mathrm{kg} \mathrm{ha}^{-1}\right) ; \mathrm{P} 0=0: 0: 0: 0: 0 ; \mathrm{P} 1=$ $25: 75: 50: 1 / 4 \times \mathrm{Al}_{\mathrm{dd}}(805): 0 ; \mathrm{P} 2=25: 75: 50: 1 / 4$ $\mathrm{x} \mathrm{Al}_{\mathrm{dd}}(805): 1,250 ; \mathrm{P} 3=50: 75: 50: 1 / 4 \mathrm{X} \mathrm{Al}_{\mathrm{dd}}(805)$ $: 2,500 ; \mathrm{P} 4=75: 150: 100: 1 / 4 \mathrm{x} \mathrm{Al}_{\mathrm{dd}}(805): 2500$; $\mathrm{P} 5=75: 150: 100: 1 / 2 \times \mathrm{Al}_{\mathrm{dd}}(1,610) ; \mathrm{P} 6=75: 150$ $: 100: 1 \times \mathrm{Al}_{\mathrm{dd}}(3,220)$ 
banyak dibanding Anjasmoro, namun Anjasmoro memiliki bobot 100 biji dua kali lebih besar dibanding Tanggamus sehingga diperoleh bobot biji yang tidak berbeda nyata.

\section{KESIMPULAN}

Kesimpulan yang diperoleh dari penelitian ini adalah pemberian dolomit $1 / 2 \times \mathrm{Al}_{\mathrm{dd}}(1,610 \mathrm{~kg})$ menurunkan kejenuhan $\mathrm{Al}$ hingga 0\%, namun pemberian dolomit 1/4 $\mathrm{X}$ $\mathrm{Al}_{\mathrm{dd}}(805 \mathrm{~kg})$ sudah dapat menurunkan kejenuhan $\mathrm{Al}$ hingga enam kali lipat serta meningkatkan $\mathrm{pH}$, kandungan $\mathrm{P}$ tersedia, $\mathrm{Ca}_{\mathrm{dd}}, \mathrm{Mg}_{\mathrm{dd}}$, dan $\mathrm{K}_{\mathrm{dd}}$. Pemberian $75 \mathrm{~kg}$ urea +150 $\mathrm{kg} \mathrm{SP}-36+100 \mathrm{~kg} \mathrm{KCl}+$ dolomit $1 / 2 \mathrm{x} \mathrm{Al}_{\text {dd }}(1,610 \mathrm{~kg}) \mathrm{ha}^{-1}$ diperoleh hasil terbaik (2.91 ton $\left.\mathrm{ha}^{-1}\right)$. Jika ketersediaan dolomit terbatas, maka dosis dolomit dapat dikurangi menjadi $1 / 4 \mathrm{X} \mathrm{Al}_{\mathrm{dd}}(805 \mathrm{~kg})$ dengan penambahan $2,500 \mathrm{~kg}$ pupuk kandang.

\section{DAFTAR PUSTAKA}

Adeli, A., K.R. Sistani, D.E. Rowe, H. Tewolde. 2005. Effects of broiler litter on soybean production and soil nitrogen and phosphorus concentrations. J. Agron. Indonesia 97:314-321.

Agustina, K., D. Sopandie, Trikoesoemaningtyas, D. Wirnas. 2010. Tanggap fisiologi akar sorgum (Sorghum bicolor L. Moench) terhadap cekaman aluminium dan defisiensi fosfor di dalam rhizotron. J. Agron. Indonesia 38:88-94.

Bachtiar, M.Ghulamahdi, M. Melati, D. Guntoro, A.Sutandi. 2015. Nitrogenase activity and plant physiological process of soybean under saturated soil culture on mineral and peaty mineral soil. IJSBAR. 24:332347.

Bandyopadhyay, K.K., A.K. Misra, P.K. Ghosh, K.M. Hati. 2010. Effect of integrated use of farmyard manure and chemical fertilizers on soilphysical properties and productivity of soybean. Soil Tillage Res. 110:115-125.

[Balitbangtan] Badan Penelitian dan Pengembangan Pertanian. 2014. Sumbedaya Lahan Pertanian Indonesia: Luas, Penyebaran, dan Potensi Ketersediaan. http//www.digilib.litbang.pertanian. [21 Desember 2015].

[Balitkabi] Balai Penelitian Tanaman Kacang-kacangan dan Umbi-umbian. 2014. Hasil penelitian utama tahun 2014. http//www.balitkabi.litbang.pertanian.go.id/[2 September 2015].

[BPS]Badan Pusat Statistik. 2015.Luas Panen, Produktivitas, dan Produksi Tanaman Pangan Menurut Provinsi (Dinamis). http//www.www.bps.go.id [5 Januari 2016].
Darwesh, D.A., P.M. Maulood, S.A. Amin. 2013. Effect of phosphorus fertilizers on growth and physiological phosphorus use efficiency of three soybean cultivars. IOSR J. Agric. Vet. Sci. 3:32-36.

Hanum, C., W.Q. Mugnisjah, S. Yahya, D. Sopandie, K. Idris, A. Sahar. 2009. Penapisan kedelai toleran cekaman aluminium dan kekeringan. Forum Pascasarjana. 32:295-305.

Kamprath, E.J. 1970. Exchangable as a criterion for liming leached mineral soils. Soil Sci. Soc. Amer. Proc. 34:252-254.

Kisinyo, P.O. 2016. Effect of lime and phosphorus fertilizer on soil chemistry and maize seedlings performance on Kenyan acid soils. Sky. J. Agric. 5:097-104.

Manshuri, A.G. 2010. Pemupukan N, P, dan K pada kedelai sesuai kebutuhan tanaman dan daya dukung lahan. Penelitian Pertanian Tanaman Pangan. 29:171-179.

Melati, M., A. Asiah, D. Rianawati. 2008. Aplikasi pupuk organik dan residunya untuk produksi kedelai panen muda. Bul. Agron. 36:204-213.

Muindi, E.M., J. Mrema, E. Semu, P. Mtakwa, C. Gachene. 2015. Effects of lime-aluminium-phosphate interactions on maize growth and yields in acid soils of the Kenya highlands. Americ. J. Agric. Forest. 3:244-252.

Noya, A.I., M. Ghulamahdi, D. Sopandie, A. Sutandi, M. Melati. 2014. Pengaruh kedalaman muka air dan amelioran terhadap produktivitas kedelai di lahan sulfat masam. Pangan 23:120-133.

Sanchez, P.A.1976. Properties and Management of Soils in the Tropics. John Wiley and Sons, New York (US).

Sudaryono, A. Wijanarko, Suyamto. 2011. Efektivitas kombinasi amelioran dan pupuk kandang dalam meningkatkan hasil kedelai pada tanah ultisol. Penelitian Pertanian Tanaman Pangan 30:43-51.

Suge, J.K., M.E. Omunyin, E.N. Omami. 2011. Effect of organic and inorganic sources of fertilizer on growth, yield and fruit quality of eggplant (Solanum melongena L). Arc. Appli. Sci. Res. 3:470-479.

Suryantini. 2014. Effect of lime, organic and inorganic fertilizer on nodulation and yield of soybean (Glycine max) varieties in ultisol soils. J. Exp. Biol. Agric. Sci. 2:78-83. 
Taufiq, A., H. Kuntyastuti,A.G. Manshuri. 2004. Fertilization and amelioration of acid dry land to increase soybean productivity. Hal. 21-40. Proceeding of Soybean Development through Integrated Crop Management. Malang 8-9 September 2003.

Taufiq, A., H. Kuntyastuti, C. Prahoro, T. Wardani. 2007. Pemberian kapur dan pupuk kandang pada kedelai di lahan kering masam. Penelitian Pertanian Tanaman Pangan 2:79-85.

Thoyyibah, S., Sumadi, A. Nuraini. 2014. Pengaruh dosis pupuk fosfat terhadap pertumbuhan, komponen hasil, hasil, dan kualitas benih dua varietas kedelai (Glycine $\max (\mathrm{L}$.$) Merr.) pada inceptisol Jatinangor.$ Agric. Sci. J. 1:111-121.

Triadiati, N.R. Mubarik, Y. Ramasita. 2013. Respon pertumbunan tanaman kedelai terhadap
Bradyrhizobium japonicum toleran masam dan pemberian pupuk di tanah masam. J. Agron. Indonesia 41:24-31.

Varma, V., A.M. Osuri. 2013. Black Spot Leaf Area Calculator, version 1.0 Beta. Bangalore, IN. National Centre for Biological Sciences.

Verde, B.S., B.O. Danga, J.N. Mugwe. 2013. Effects of manure, lime and mineral $\mathrm{P}$ fertilizer on soybean yields and soil fertility in a humic nitisol in the Central Highlands of Kenya. Internat. J. Agric. Sci. Res. 2:283-291.

Yunizar. 2014. Pengaruh tiga taraf masukan terhadap beberapa varietas kedelai di lahan kering masam di daerah Tandun, Provinsi Riau. J. Agrotek. Trop. $3: 12-18$ 